the sympathetic and lucid account of Freudian psychopathology to find that his therapeutic methods are denied-Dr. Smith has clearly a great admiration for Harry Stack Sullivan, but his recommended technique, 'The therapist must direct the treatment . . . the expert does not permit people to tell him things so beside the point that only God could guess how they happened to get into the account,' is contrary to all the accepted free association methods of psychotherapy.

There are chapters on the sociopathic personality and the alcoholic, and these are followed by a full description of current psychiatric opinion on the affective disorders and schizophrenia.

The chapters on epilepsy, child psychiatry and geriatrics conform to the scholarly standard of the whole work.

This book is beautifully printed and produced and reflects great credit on the publishers and printers.

Dr. Smith's book can be warmly welcomed by those interested in the education of medical students and would form a valuable addition to the library of nurses' training schools.

\section{EXPERIMENTAL SURGERY}

By J. Markowitz, J. Archibald, and H. G. DownIE. Fourth edition. Pp. xii + 93I. 580 illustrations and 16 colour plates. London: Baillière, Tindall \& Cox Ltd. I960. Ioos.

This book is intended to be of value to students and graduates of surgery, physiology and veterinary medicine. However, in being directed to such a wide variety of readers, the text lacks consistency. The style varies greatly from an erudite philosophical appraisal of surgical teaching to a mundane discussion of kennel management. The cause of vivisection is vigorously championed and a strong plea is made for learning surgical technique on animals rather than man.

The main portion of this book is devoted to a variety of surgical procedures that can be performed on dogs. The operations range from exceedingly elementary manipulations, to highly complicated techniques. The reason for performing the procedures is often merely to serve as 'Student Exercise'. However, relevant physiological and clinical considerations are discussed and references to original work are included.

The book is well produced with excellent print and illustrations.

\section{OUTLINE OF ORTHOPAEDICS}

By J. Crawford Adams. Third edition. Pp. vii + 440. Illustrated. London and Edinburgh: E. \& S. Livingstone Ltd. r 960 . 35s.

Yet another edition of this book demonstrates its popularity. It fulfils its function as an outline of orthopaedics well and there is not much more reading required that would not suffice for postgraduate degrees, but the material contained is essentially for undergraduates.

The description of the clinical examination of each region at the beginning of the respective chapters is especially valuable, although there is no mention of the patello-femoral joint in the examination of the knee.

The diagrams are simple but functional and clarify the text, but some of the $\mathrm{X}$-rays suffer from the usual faults in reproduction and could well have been omitted.

The space given to some sections appears out of proportion and, whereas the important section on the interpretation of radiographs is condensed into one page, the much less important subject of electrodiagnosis cxtends to two, but generally the important sections are more comprehensive.

This book is a valuable, small, but essentially complete addition to the undergraduate's already overflowing library.

\section{FRACTURES, DISLOCATIONS AND SPRAINS}

By Philip Wiles, M.S., F.R.C.S. Pp. 67, illustrated. London: J. \& A. Churchill Ltd. 1960. 27s. $6 \mathrm{~d}$.

That Mr. Wiles has a flair for teaching is, of course, well known from his textbook of orthopaedic surgery. In this present work, a kind of atlas, he has succeeded in reducing the essentials of fracture treatment to simple terms capable of quick assimilation by medical students, casualty officers, general practitioners and others concerned with the treatment of the injured.

The special activities of the Middlesex Hospital in the way of the care of athletic injuries and of patients suffering from malignant disease is reflected in short accounts of fatigue fractures and of pathological fractures, the latter being frequently treated by bold methods of internal fixation.

The book is packed with excellent line drawings and clear radiographs, while the text, though condensed, is sufficient to give clear guidance. As a rule each pair of opposing pages consists of carefully selected radiographs on the left and of line drawings and text on the right. A succession of titles chosen at random reads like this: Pelvis, Hip-dislocation, Femur-neck, Femur-shaft, Knee-fractures, Knee-ligamentous injuries, $\mathrm{Pa}$ tella and extensor mechanism.

From this it will be clear that the book is simply first class for the purpose of rapid revision. It will be warmly welcomed not only by those for whom the book is specially written, but also those responsible for the teaching of this important subject. For workers overseas it forms an excellent introduction to current practice in England. 